\title{
Stoichiometry of dissolved organic matter and the kinetics of its microbial degradation in a coastal upwelling system
}

\author{
Christian Lønborg ${ }^{1,2, *}$, Xosé A. Álvarez-Salgado ${ }^{1}$, Sandra Martínez-García ${ }^{3}$, \\ Axel E. J. Miller ${ }^{2}$, Eva Teira ${ }^{3}$ \\ ${ }^{1}$ CSIC, Instituto de Investigacións Mariñas, Eduardo Cabello 6, 36208 Vigo, Spain \\ ${ }^{2}$ Scottish Association for Marine Science, Oban, Argyll PA37 1QA, UK \\ ${ }^{3}$ Departamento de Ecoloxía e Bioloxía Animal, Universidade de Vigo, 36200 Vigo, Spain
}

\begin{abstract}
The degradation of dissolved organic carbon (DOC), nitrogen (DON) and phosphorus (DOP) collected in the coastal upwelling system of the Ría de Vigo (NW Iberian Peninsula) was assessed following the time-course of DOC, DON and DOP concentrations in laboratory incubations. Initial concentrations varied from 73 to $94 \mu \mathrm{M}$ for DOC, 4.5 to $7.2 \mu \mathrm{M}$ for DON and 0.12 to $0.32 \mu \mathrm{M}$ for DOP. The bioavailable fraction (BDOM) represented $17 \pm 6 \%$ (average \pm SE) of DOC, $38 \pm 6 \%$ of DON and $65 \pm 9 \%$ of DOP. BDOM was significantly correlated with temperature $\left(R^{2}>0.3, p<0.05\right)$ and chlorophyll a $\left(\mathrm{R}^{2}>0.5, \mathrm{p}<0.05\right)$, indicating that the differences in DOM bioavailability were associated with the seasonal variations in plankton biomass and activity. The C:N:P stoichiometry of BDOM, $111( \pm 38): 18( \pm 6): 1$, was not significantly different from the Redfield ratio (106:16:1), pointing to a phytoplankton origin of BDOM. Accordingly, exponential rate constants of BDOM suggest that this pool is very labile. Despite the reduced flushing times of the Ría de Vigo, from 3 to $8 \mathrm{~d}$, as much as $70 \pm 13 \%$ of BDOC (average \pm SD), $81 \pm 8 \%$ of BDON and $88 \pm 5 \%$ of BDOP are mineralized within the embayment. The remaining C-rich BDOM is exported to the adjacent oligotrophic waters, suggesting that the offshore transport of labile DOM must be accounted for when considering the carbon balance of ocean surface waters adjacent to productive coastal areas.
\end{abstract}

KEY WORDS: DOM - Bioavailability · Degradation - Stoichiometry · Biochemical composition · Coastal upwelling

Resale or republication not permitted without written consent of the publisher

\section{INTRODUCTION}

Dissolved organic matter (DOM) is metabolically important in marine systems, supplying both energy (C) and nutrients (N, P) to prokaryotes (Azam 1998). DOM consists of a small labile pool with short turnover times (hours to days), a semi-labile pool with longer turnover times (weeks to months) and a recalcitrant background (Carlson \& Ducklow 1995). Recent studies have shown that both autochthonous and allochthonous DOM can be metabolized by bacteria (Moran \& Hodson 1990), with the bioavailability depending on molecular size (Amon \& Benner 1996) and chemical composition (Benner \& Opsahl 2001). In open oceans and coastal waters, not influenced by huge terrestrial inputs, bioavailable DOM has an autochthonous origin, which is considered as a mix of carbohydrates, lipids, proteins and phosphorus compounds (ÁlvarezSalgado et al. 2006).

The old radiocarbon age of deep-water DOM (Williams \& Druffel 1987, Druffel et al. 1992) indicates that it is resistant to biological utilization. The depth distribution of DOM has therefore been used to quantify the bioavailable DOM (BDOM) by subtraction of deep-water DOM from surface water concentrations and the difference yielding the bioavailable pool (Carlson 2002). An alternative method used to quantify $\mathrm{BDOM}$ is the application of microbial bioassay experi- 
ments, which provide an estimate of the labile fraction as well as the turnover rates. However, most studies using microbial incubations have only conducted single experiments with restricted spatial and time resolution.

DOM contains $\mathrm{C}, \mathrm{N}$ and $\mathrm{P}$ in an average ratio of 300:22:1 (Benner 2002), and thus is depleted in $\mathrm{N}$ and $\mathrm{P}$ compared to the average phytoplankton biomass $\mathrm{C}: \mathrm{N}: \mathrm{P}$ ratio of 106:16:1 (Redfield et al. 1963). The turnover of DOM has been proposed to sequentially proceed with DOP being more bioavailable than DON, which in turn is more bioavailable than DOC (Hopkinson et al. 1997, 2002). This order has been used to explain why marine DOM is enriched in $\mathrm{C}$ over $\mathrm{N}$ and even more depleted in $\mathrm{P}$ compared with the Redfield ratio, suggesting that $\mathrm{N}$ and $\mathrm{P}$ depletion of DOM could be linked with age (Williams 1995). However, other studies have shown that freshly produced autochthonous DOM can have high C:N ratios due to large production of carbohydrates (Fajon et al. 1999), proposing that linking DOM age with $\mathrm{N}$ and $\mathrm{P}$ depletion is not valid under all conditions.

The study of the bioavailability and rate constants of DOM is especially relevant in coastal upwelling systems because they are sites of large, episodic phytoplankton blooms leading to enhanced DOM production resulting from upwelling of nutrient-rich bottom waters (Chavez \& Toggweiler 1995, Hansell \& Carlson 1998a). In the present study, we (1) estimated the bioavailability of DOC, DON and DOP over an annual cycle, (2) assessed the biochemical composition of the DOM mineralized and (3) determined the DOM rate constants using laboratory incubations in the highly dynamic coastal upwelling area of the Ría de Vigo (NW Iberian Peninsula).

\section{MATERIALS AND METHODS}

Study area. The Ría de Vigo has a length of $33 \mathrm{~km}$, a surface area of $176 \mathrm{~km}^{2}$ and a volume of $3.32 \mathrm{~km}^{3}$. The hydrography of the ría is influenced by wind-driven upwelling and downwelling episodes; northerly winds, which predominate from April to October, produce upwelling of the cold and nutrient-rich Eastern North Atlantic Central Water (ENACW), resulting in high productivity. In contrast, southerly winds dominate from November to March, resulting in downwelling, forcing warm and nutrient-poor shelf surface water into the ría (Álvarez-Salgado et al. 2003). Wind- driven upwelling enhances the positive residual circulation pattern of the ría, i.e. the inflow of cold and nutrient-rich bottom waters and the compensating outflow of warm and nutrient-poor surface waters, resulting in a proportional reduction of the renewal time of the ría (Álvarez-Salgado et al. 2001, 2008). A reversal of the circulation occurs under wind-driven downwelling conditions, which results in the entry of the warm and nutrient-poor shelf surface waters into the ría that is compensated by the evacuation of the water in the river through the bottom layer (Álvarez-Salgado et al. 2001, 2008). The river Oitabén-Verdugo, the main tributary to the Ría de Vigo, flows into San Simon Bay, at the innermost reaches of the embayment (Fig. 1). With an average annual flow of $15 \mathrm{~m}^{3} \mathrm{~s}^{-1}$ and a pristine composition $(<20 \mu \mathrm{M}$ inorganic $\mathrm{N},<0.3 \mu \mathrm{M}$ phosphate, $<120 \mu \mathrm{M}$ DOC, $<10 \mu \mathrm{M}$ DON and $<0.4 \mu \mathrm{M}$ DOP; Gago et al. 2005), its impact on the circulation and biogeochemistry of the Ría de Vigo is minor and restricted to the inner parts of the ría.

The study site was near the main channel in the middle sector of the ría (Fig. 1). Previous studies in the Ría de Vigo (Nogueira et al. 1997, Álvarez-Salgado et al. 2001) have shown that this location is appropriate for evaluating the biogeochemical processes occurring in the pelagic Ría de Vigo with the exception of the innermost reaches of the embayment, where the river Oitabén-Verdugo enters the shallow sedimentary basin of San Simon Bay. Water for the laboratory incubation experiments was collected in autumn (20 and 27 September, 4 October 2007), winter (31 January, 7 and 14 February 2008), spring (17 and 24 April 2008) and

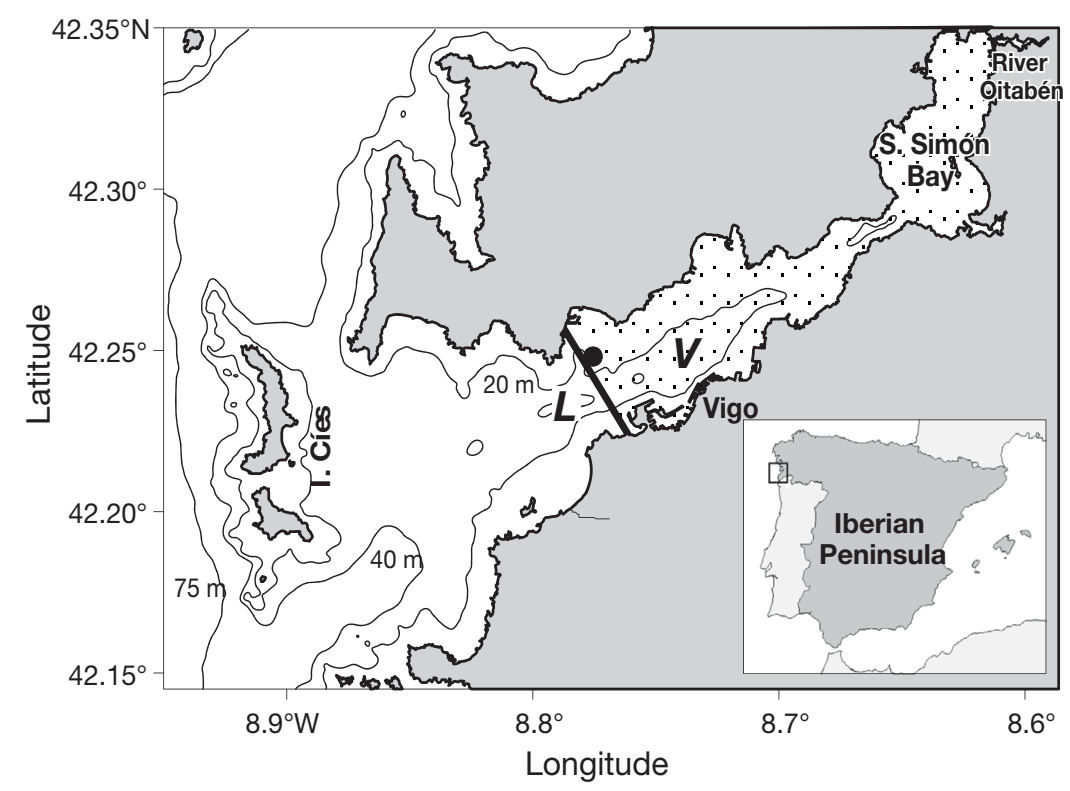

Fig. 1. Sampling station (๑) in the Ría de Vigo, NW Spain. V: area used for calculating the volume of the embayment; $L$ : length of the open end of the embayment at the sampling site 
summer (26 June, 3 and 7 July 2008) with a 251 Niskin bottle at $5 \mathrm{~m}$ depth, and combined into a $50 \mathrm{l}$ acidwashed container. Salinity and temperature profiles were recorded prior to water collection with an SBE 9/11 CTD probe. Chlorophyll a ( $\mathrm{chl} \mathrm{a)} \mathrm{was} \mathrm{measured}$ by filtering between 100 and $200 \mathrm{ml}$ of the sample water through $\mathrm{GF} / \mathrm{F}$ filters, which were frozen at $-20^{\circ} \mathrm{C}$ until analysis. Chl a was determined $\left( \pm 0.05 \mathrm{mg} \mathrm{l}^{-1}\right.$ precision) with a Turner Designs 10000R fluorometer after $90 \%$ acetone extraction (Yentsch \& Menzel 1963).

Renewal time estimates. Following Wooster et al. (1976), daily offshore Ekman transport values $\left(-Q_{\mathrm{X}}, \mathrm{m}^{3}\right.$ $\mathrm{s}^{-1} \mathrm{~km}^{-1}$ ), a rough estimation of the volume of water downwelled/upwelled per $\mathrm{km}$ of coast, can be calculated as:

$$
-Q_{\mathrm{X}}=\frac{\rho_{\mathrm{air}} \cdot C \cdot|W| \cdot W_{\mathrm{y}}}{\rho_{\mathrm{SW}} \cdot f}
$$

where $\rho_{\text {air }}$ is the density of air, $1.22 \mathrm{~kg} \mathrm{~m}^{-3}$ at $15^{\circ} \mathrm{C}_{;} C$ is an empirical drag coefficient (dimensionless), $1.3 \times$ $10^{-3} ; f$ is the Coriolis parameter, $9.946 \times 10^{-5} \mathrm{~s}^{-1}$ at $43^{\circ}$ latitude; $\rho_{\mathrm{SW}}$ is the density of seawater, $\sim 1025 \mathrm{~kg} \mathrm{~m}^{-3}$; $|W|$ is the wind speed; and $W_{\mathrm{y}}$ is the northwards component. Average daily geostrophic winds were estimated from atmospheric surface pressure charts, provided at $6 \mathrm{~h}$ intervals by the Spanish Instituto Nacional de Meteorología. Positive values indicate upwelling, and negative values downwelling.

The renewal time of the ría can be calculated from the offshore Ekman transport following ÁlvarezSalgado et al. (2008):

$$
t=\frac{n}{\sum_{i}^{n}\left|Q_{\mathrm{xi}}\right|} \cdot \frac{V}{L}
$$

where $\left|Q_{\mathrm{X}}\right|$ is the absolute value of the daily offshore Ekman transport-a $7 \mathrm{~d}$ running-mean centered on the sampling date was used $(n=7)-V$ is the volume of the embayment from the inner reaches to the sampling site $\left(0.53 \times 10^{9} \mathrm{~m}^{3}\right)$ and $L\left(2.50 \times 10^{3} \mathrm{~m}\right)$ is the length of the open end of the embayment at the sampling site (see Fig. 1).

Experimental design. Filtration of the sample water started within $10 \mathrm{~min}$ of collection; one part was filtered through a pre-washed (>10 l Milli-Q water) dualstage $(0.8$ and $0.2 \mu \mathrm{m})$ filter cartridge (Pall, AcroPak Supor Membrane) and the second part was filtered through pre-combusted $\left(450^{\circ} \mathrm{C}\right.$ for $\left.4 \mathrm{~h}\right) \mathrm{GF} / \mathrm{C}$ filters to remove larger phytoplankton and grazers and establish a microbial culture. After filtration, the water was kept in the dark until arrival in the laboratory (within $2 \mathrm{~h}$ ). The water was transferred into a $20 \mathrm{l}$ carboy and the microbial inoculum was added to the $0.2 \mu \mathrm{m}$ filtrate, corresponding to $10 \%$ of the total volume. The water was distributed into 16 glass bottles $(500 \mathrm{ml})$ and incubated in the dark at a constant temperature of $15^{\circ} \mathrm{C}$, with 4 replicate bottles being analyzed for each subsampling at Day 0, 4, 12 and 53 or 70 (summer experiments only). All glassware used in the experiments was acid-washed and rinsed with Milli-Q water prior to use. Samples for the analysis of the dissolved phase were collected in 4 replicates by filtration through $0.2 \mu \mathrm{m}$ filters (Pall, Supor Membrane Disc Filter) for subsequent analysis of the concentration of (1) dissolved inorganic nitrogen (DIN; $\mathrm{NH}_{4}, \mathrm{NO}_{2}^{-}$and $\mathrm{NO}_{3}{ }^{-}$), (2) dissolved inorganic phosphorus (DIP; $\mathrm{HPO}_{4}{ }^{-2}$ ), (3) DOC, (4) total dissolved nitrogen (TDN) and (5) total dissolved phosphorus (TDP). The DIN, DIP and TDP subsamples were collected into $50 \mathrm{ml}$ acidwashed polyethylene bottles and DOC and TDN samples into pre-combusted $\left(450^{\circ} \mathrm{C}, 12 \mathrm{~h}\right)$ glass ampoules and preserved with $50 \mu \mathrm{l} 25 \% \mathrm{H}_{2} \mathrm{PO}_{4}$ for each $10 \mathrm{ml}$ of sample.

Sample analysis. DOC and TDN samples were measured using a Shimadzu total organic carbon analyzer (platinum catalyst) connected to an Antek TN measuring unit. Using the deep ocean reference (Sargasso Sea deep water, $2600 \mathrm{~m}$ ) we obtained a concentration of $46.8 \pm 2.8 \mu \mathrm{M}$ (average $\pm \mathrm{SD}$ ) for DOC and $22.0 \pm$ $2.0 \mu \mathrm{M}$ for TDN. The nominal value for DOC provided by the reference laboratory was $44.0 \pm 1.5 \mu \mathrm{M}$, while the TDN value provided was $21.8 \pm 0.8 \mu \mathrm{M}$. Standards for DOC and TDN were made from potassium hydrogen phthalate and glycine, with the concentrations of DOC and TDN calculated using a daily calibration curve with 4 points and subtraction of a blank value. DON concentrations were calculated as the difference between TDN and DIN (DON = TDN - DIN) with the standard error calculated as the sum of the contributions: $\mathrm{SE}^{2}{ }_{\mathrm{DON}}=\mathrm{SE}^{2}{ }_{\mathrm{TDN}}+\mathrm{SE}^{2}{ }_{\mathrm{NH}}+\mathrm{SE}^{2}{ }_{\mathrm{NO} 2}+\mathrm{SE}^{2}{ }_{\mathrm{NO}}$.

Inorganic nutrients $\left(\mathrm{NH}_{4}, \mathrm{NO}_{2}{ }^{-}, \mathrm{NO}_{3}{ }^{-}\right.$and $\left.\mathrm{HPO}_{4}{ }^{-2}\right)$ were determined by standard segmented flow analysis (SFA). The precisions were $\pm 0.02 \mu \mathrm{M}$ for nitrite, $\pm 0.1 \mu \mathrm{M}$ for nitrate, $\pm 0.05 \mu \mathrm{M}$ for ammonium and $\pm 0.02 \mu \mathrm{M}$ for phosphate. TDP was measured by the ammonium molybdate method as inorganic phosphorus after a wet oxidation $\left(120^{\circ} \mathrm{C}, 75 \mathrm{~min}\right)$ in acid persulphate (Hansen \& Koroleff 1999). The detection of TDP was performed in an SFA system using a daily calibration curve. The oxidation efficiency was tested daily with adenosine 5 '-triphosphate (ATP) obtaining recoveries between 90 and 100\%. DOP was calculated as the difference between TDP and DIP (DOP = TDP DIP) with the SE for DOP calculated as $\mathrm{SE}^{2}{ }_{\mathrm{DOP}}=\mathrm{SE}^{2} \mathrm{TDP}$

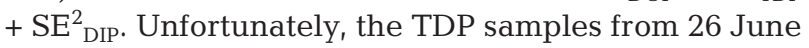
2008 were under the detection limit of the method used, probably due to an unusually low recovery during that measuring day (ATP $<80 \%$ ).

The decay of DOM during the course of the incubations was modelled by a first-order exponential decay 
function using the Marquardt-Levenberg algorithm and taking the refractory pool into account:

$$
\operatorname{DOM}(t)=\mathrm{BDOM} \cdot \exp \left(-k_{\mathrm{DOM}} \cdot t\right)+\mathrm{RDOM}
$$

where BDOM is the bioavailable pool $(\mu \mathrm{M}), k_{\mathrm{DOM}}$ the rate constant $\left(\mathrm{d}^{-1}\right), t$ the time $(\mathrm{d})$ and RDOM the remaining pool after $53 / 70 \mathrm{~d}$ of incubation $(\mu \mathrm{M})$. In the present study, BDOM was defined as $\mathrm{BDOM}=\mathrm{DOM}_{0}-$ RDOM, where $\mathrm{DOM}_{0}$ is the initial DOM concentration. Note that since BDOM and RDOM are calculated prior to adjusting the time evolution of DOM, the only parameter that is adjusted with Eq. (3) is $k_{\mathrm{DOM}}$. Days 0, 4,12 and 53 or 70 (summer experiments only) were considered in the calculation of $k_{\mathrm{DOM}}$.

Conversion of $\mathrm{C}: \mathrm{N}: \mathrm{P}$ stoichiometry into biochemical composition. Assuming that changes in the $C: N: P$ composition of BDOM are due to variations in the proportions of the 4 major groups of biomolecules produced and released by phytoplankton (carbohydrates, lipids, proteins and $\mathrm{P}$ compounds) rather than variations in the molecular formula of each group (ÁlvarezSalgado et al. 2006), it is possible to estimate their proportions as stated by Fraga et al. (1998). The typical elemental composition of proteins (Prt), carbohydrates (Cho), lipids (Lip) and P compounds (Pho) are shown in Table 1. The chemical formula of the $\mathrm{P}$ compounds results from the contribution of RNA, DNA, nucleotides, phospholipids, phosphoproteins, phosphosugars and cellular phosphates and polyphosphates in the average proportions provided by Miyata \& Hattori (1986). From these chemical formulas, the contribution of the different biomolecules to the degraded BDOM can be calculated from changes in DOC, DON and DOP with the following sets of equations:

$$
\begin{gathered}
\mathrm{C}_{138} \mathrm{H}_{217} \mathrm{O}_{45} \mathrm{~N}_{39} \mathrm{~S}+144 \mathrm{O}_{2}+103 \mathrm{OH}^{-} \rightarrow 138 \mathrm{HCO}_{3}{ }^{-}+ \\
39 \mathrm{NO}_{3}{ }^{-}+\mathrm{SO}_{4}{ }^{2-}+15 \mathrm{H}_{2} \mathrm{O} \\
\mathrm{C}_{6} \mathrm{H}_{10} \mathrm{O}_{5}+6 \mathrm{O}_{2}+6 \mathrm{OH}^{-} \rightarrow 6 \mathrm{HCO}_{3}{ }^{-}+5 \mathrm{H}_{2} \mathrm{O}
\end{gathered}
$$

Table 1. Chemical composition of the main organic products of the synthesis and early degradation of marine phytoplankton, according to Fraga et al. (1998). Percent contribution (in weight $[\mathrm{w}]$ ) corresponds to the average composition of marine phytoplankton

\begin{tabular}{|llc|}
\hline & Chemical formula & $\begin{array}{c}\text { Contri- } \\
\text { bution } \\
(\%, w / w)\end{array}$ \\
\hline Proteins & $\mathrm{C}_{138} \mathrm{H}_{217} \mathrm{O}_{45} \mathrm{~N}_{39} \mathrm{~S}$ & 46 \\
Carbohydrates & $\mathrm{C}_{6} \mathrm{H}_{10} \mathrm{O}_{5}$ & 23 \\
Lipids & $\mathrm{C}_{53} \mathrm{H}_{89} \mathrm{O}_{6}$ & 18 \\
Phosphorus compounds & $\mathrm{C}_{45} \mathrm{H}_{76} \mathrm{O}_{31} \mathrm{~N}_{12} \mathrm{P}_{5}$ & 12 \\
Pigments & $\mathrm{C}_{46} \mathrm{H}_{52} \mathrm{O}_{5} \mathrm{~N}_{4} \mathrm{Mg}$ & 2 \\
Average composition & $\mathrm{C}_{106} \mathrm{H}_{171} \mathrm{O}_{41} \mathrm{~N}_{16} \mathrm{P}$ & 100 \\
\hline
\end{tabular}

$$
\begin{gathered}
\mathrm{C}_{53} \mathrm{H}_{89} \mathrm{O}_{6}+72.25 \mathrm{O}_{2}+53 \mathrm{OH}^{-} \rightarrow 53 \mathrm{HCO}_{3}{ }^{-}+ \\
44.5 \mathrm{H}_{2} \mathrm{O} \\
\mathrm{C}_{45} \mathrm{H}_{76} \mathrm{O}_{31} \mathrm{~N}_{12} \mathrm{P}_{5}+47.75 \mathrm{O}_{2}+45 \mathrm{OH}^{-} \rightarrow 45 \mathrm{HCO}_{3}{ }^{-}+ \\
12 \mathrm{NO}_{3}{ }^{-}+5 \mathrm{HPO}_{4}{ }^{2-}+13.5 \mathrm{H}_{2} \mathrm{O}
\end{gathered}
$$

The corresponding linear system of mass balance equations is:

$$
\begin{gathered}
\text { BDOC }=138 \text { Prt }+6 \text { Cho }+53 \text { Lip }+45 \text { Pho } \\
\text { BDON }=39 \text { Prt }+12 \text { Pho } \\
\text { BDOP }=5 \text { Pho }
\end{gathered}
$$

A system of 3 equations with 4 unknowns (Cho, Lip, Prt and Pho) does not have a unique solution. Whereas the amounts of Prt and Pho are determined by Eqs. (9) and (10), the amounts of Cho and Lip are undetermined. Following Álvarez-Salgado et al. (2006), we calculated the range of possible biochemical compositions compatible with a mineralization of at least $5 \%$ of Cho on one extreme and at least $5 \%$ of Lip on the other extreme.

Statistical analysis. Regression analyses were performed using the best-fit between the 2 variables $\mathrm{X}$ and Y obtained by regression model II as described in Sokal \& Rohlf (1995). In the cases where the intercept was not significantly different from zero, it was set to zero and a new slope was calculated. Prior to the regressions, normality was checked and the confidence level was set at $95 \%$ with all statistical analyses conducted in Statistica 6.0.

\section{RESULTS AND DISCUSSION}

\section{Hydrography}

During the autumn surveys, the Ekman transport indicated an initial strong upwelling event $\left(-Q_{\mathrm{X}}=\right.$ $551 \mathrm{~m}^{3} \mathrm{~s}^{-1} \mathrm{~km}^{-1}$ ) followed by upwelling relaxation (27 September 2007) and moderate downwelling (04 October 2007), resulting in a longer flushing time from 4 to $11 \mathrm{~d}$. During this period, surface salinity was around 35.5, whereas temperature decreased from $>16$ to $<14^{\circ} \mathrm{C}$. Ambient $\mathrm{chl}$ a levels decreased from 3.2 to $2.8 \mathrm{mg} \mathrm{m}^{-3}$ and DIN increased from 3 to $13 \mu \mathrm{M}$ (Fig. 2). During the winter surveys, the conditions evolved from relaxation to strong downwelling and resulted in water flushing times varying between 3 and $18 \mathrm{~d}$. Salinity was around 35 and surface temperatures were between 13.0 and $13.5^{\circ} \mathrm{C}$. Chl a levels were $<1.5 \mathrm{mg} \mathrm{m}^{-3}$ and DIN concentrations were maintained above $8 \mu \mathrm{M}$ (Fig. 2). The spring surveys were dominated by moderate downwelling conditions, and flushing times varied 


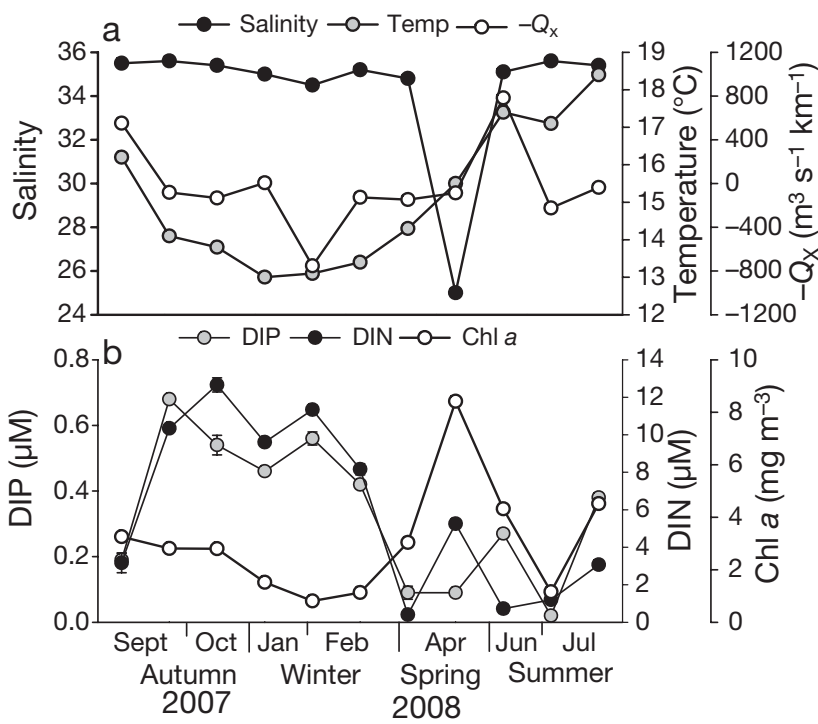

Fig. 2. Field conditions in the Ría de Vigo at the sampling site (5 m depth) during 2007 to 2008, with (a) salinity, temperature and the $7 \mathrm{~d}$ running-mean of offshore Ekman transport $\left(-Q_{\mathrm{X}}\right)$ and (b) dissolved inorganic P (DIP), N (DIN) and chlorophyll a (chl a) concentrations. Error bars are SD

between 6 and 9 d. Salinity was relatively low, probably caused by high precipitation (153.7 mm during April were recorded in the terrace of the host laboratory). Salinity reached its lowest and chl a its highest level on 24 April 2008, with values of 25 and $>8 \mathrm{mg}$ $\mathrm{m}^{-3}$, respectively. Phosphate was relatively low at $<0.1 \mu \mathrm{M}$, whereas DIN levels were $>5 \mu \mathrm{M}$ (Fig. 2), possibly due to the high $\mathrm{N}: \mathrm{P}$ molar ratio of the nutrient transported by terrestrial runoff (45; Gago et al. 2005). During the summer surveys, initial strong upwelling was followed by moderate downwelling. The calculated average water flushing times varied between 3 and $9 \mathrm{~d}$. Salinities were stable at $>35$ and temperatures were high at $>17^{\circ} \mathrm{C}$. Low DIN levels of $<3 \mu \mathrm{M}$ and chl a concentrations ranging from 1.1 to $4.5 \mathrm{mg} \mathrm{m}^{-3}$ were recorded (Fig. 2).

The hydrographic conditions at $5 \mathrm{~m}$ depth during the present study were within the natural ranges of variability found in long-term studies conducted in the Ría de Vigo (Nogueira et al. 1997).

\section{DOM bioavailability}

Initial DOC concentrations varied between 73 and $94 \mu \mathrm{M}$, while DON and DOP ranged from 4.5 to $7.2 \mu \mathrm{M}$ and 0.12 to $0.32 \mu \mathrm{M}$, respectively (Fig. 3), which is comparable with previous measurements performed in the Ría de Vigo (Doval et al. 1997, Álvarez-Salgado et al. 2006). BDOC varied between 7 and $29 \mu \mathrm{M}$, representing $17 \pm 6 \%$ of DOC (average $\pm \mathrm{SE}$ ); BDON ranged

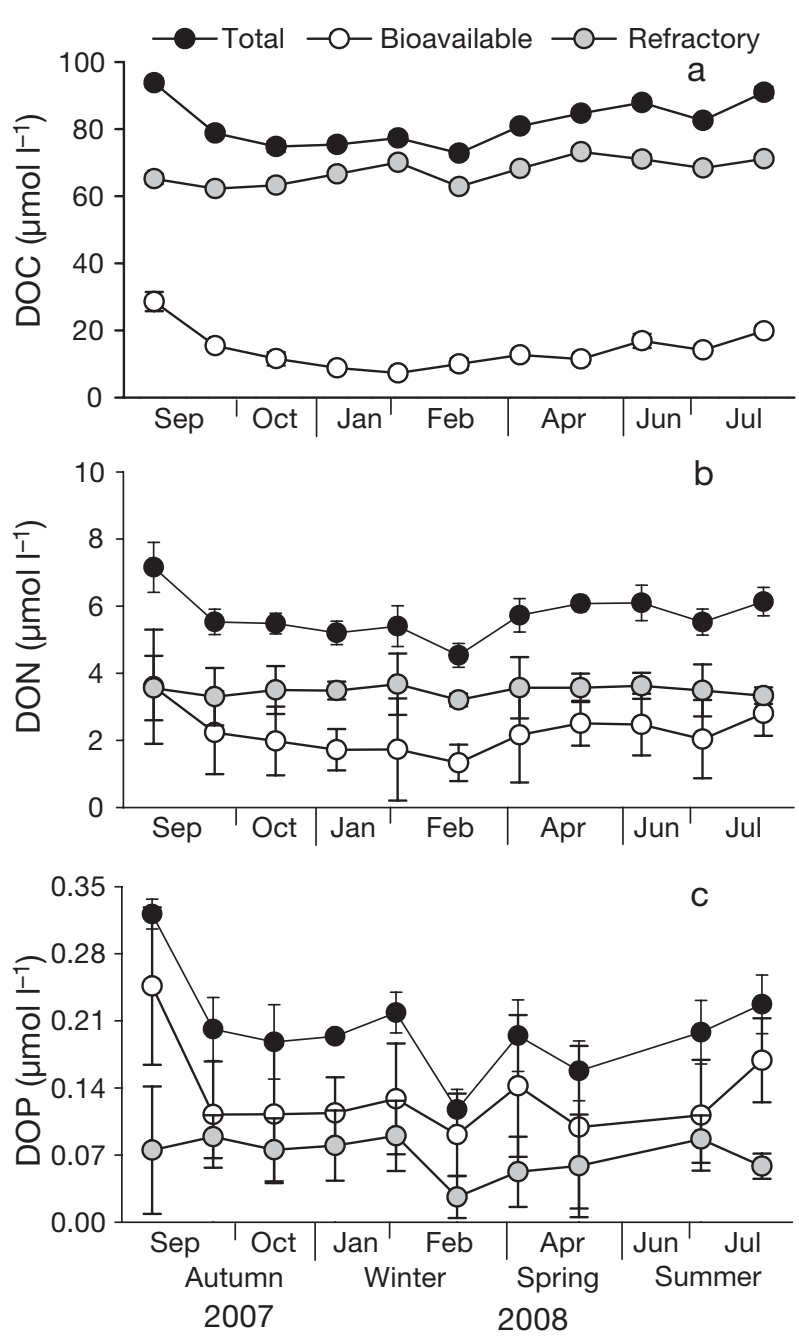

Fig. 3. Temporal variability in total, bioavailable and refractory dissolved organic C (DOC), N (DON and P (DOP) concentrations. Error bars are SE

between 1.3 and $3.6 \mu \mathrm{M}$, corresponding to $38 \pm 6 \%$ of the DON; and BDOP reached values between 0.09 and $0.25 \mu \mathrm{M}$, representing $65 \pm 9 \%$ of DOP (Fig. 3). The percentages of BDOC were comparable with the $19 \pm$ $12 \%$ reported for other coastal areas (Søndergaard \& Middelboe 1995, Lønborg \& Søndergaard 2009). BDON values were also similar to previous estimates, 30 \% (Bronk 2002, Lønborg \& Søndergaard 2009), as were BDOP values: previously reported levels ranged from 60 to $80 \%$ (Hopkinson et al. 2002, Nausch \& Nausch 2006, Lønborg et al. 2009). A positive linear relationship occurred between the BDOM and DOM pools (Table 2), with slopes not significantly different from 1. These slopes suggest that when BDOM concentrations increased by $1 \mu \mathrm{M}$, total DOM increased by $1 \mu \mathrm{M}$, demonstrating that the seasonal variations in DOM were due to the BDOM pool, as previously found 
Table 2. Linear regressions between bioavailable dissolved organic matter (BDOM) and DOM, inorganic nutrients (dissolved inorganic N and P; DIN, DIP) and rate constants $\left(k_{\mathrm{DOC}}, k_{\mathrm{DON}}\right.$ and $\left.k_{\mathrm{DOP}}\right)$ obtained by fitting the exponential degradation of dissolved organic $\mathrm{C}, \mathrm{N}$ and $\mathrm{P}$ (DOC, DON and DOP) with time. Slope, intercept and SE are values found by Model II regression. $\mathrm{R}^{2}$ : Coefficient of determination; ns: not significant

\begin{tabular}{|lccccc|}
\hline $\mathrm{X}$ & $\mathrm{Y}$ & Slope $( \pm \mathrm{SE})$ & Intercept $( \pm \mathrm{SE})$ & $\mathrm{R}^{2}$ & $\mathrm{p}$ \\
\hline BDOC & DOC & $1.1 \pm 0.2$ & $65 \pm 3$ & 0.73 & $<0.001$ \\
BDON & DON & $1.1 \pm 0.1$ & $3.3 \pm 0.2$ & 0.95 & $<0.001$ \\
BDOP & DOP & $0.9 \pm 0.1$ & $0.09 \pm 0.02$ & 0.80 & $<0.001$ \\
BDON & DIN & $-0.14 \pm 0.05$ & $2.81 \pm 0.21$ & 0.30 & $<0.05$ \\
BDOP & DIP & $-0.15 \pm 0.08$ & $0.20 \pm 0.06$ & 0.36 & $<0.05$ \\
BDOC & $k_{\text {DOC }}$ & $(13 \pm 2) \times 10^{-3}$ & $n s$ & 0.84 & $<0.0001$ \\
BDON & $k_{\text {DON }}$ & $0.13 \pm 0.03$ & $n s$ & 0.66 & $<0.002$ \\
BDOP & $k_{\text {DOP }}$ & $2.8 \pm 0.3$ & $n s$ & 0.86 & $<0.02$ \\
& & & $n$ & & \\
\hline
\end{tabular}

The contribution of DON and DOP to the mineralization of inorganic nutrients has previously been calculated as the slope between BDON/DIN and BDOP/DIP (Hopkinson et al. 1997) (Table 2). We found that $14 \pm 9 \%$ of DIN and $15 \pm 8 \%$ of DIP originated from the degradation of DON and DOP, which is comparable with previous estimates for the Ría de Vigo (Álvarez-Salgado et al. 2006).

\section{DOM biochemical composition}

The range of possible biochemical composition of BDOM (Table 4) was calculated introducing the C:N:P (Williams 1995). The origin intercepts of these regressions indicated the incubation end concentrations of DOM: $65 \pm 3 \mu \mathrm{M}$ for DOC, $3.3 \pm 0.2 \mu \mathrm{M}$ for DON, and $0.09 \pm 0.02 \mu \mathrm{M}$ for DOP (Table 2). These values are comparable with background levels measured in the bottom waters (40 m depth) of the Ría de Vigo (Doval et al. 1997, Álvarez-Salgado et al. 2006) and with the average refractory DOM end-point concentrations in our incubations. Comparing our incubation end levels with the concentrations found in the deep sea, we find that they are around twice as high for DOC (35 to $45 \mu \mathrm{M}$, Hansell \& Carlson 1998b), while the refractory DON and DOP levels of the Ría de Vigo are comparable with those found in the deep sea, $<3$ and $0.02 \mu \mathrm{M}$, respectively (Hopkinson et al. 1997, Bronk, 2002).

BDOM significantly correlated with temperature and chl a (Table 3), indicating that the differences in DOM bioavailability were related to the seasonal variations in plankton biomass and activity.

Table 3. Matrix of the correlation coefficient $\left(\mathrm{R}^{2}\right)$ of the significant $(\mathrm{p}<0.05)$ linear regressions between bioavailable dissolved organic C (BDOC), N (BDON), P (BDOP), proteins (Prt) and lipids and carbohydrates (Lip + Cho) with physical and chemical parameters from Ría de Vigo. DIN, DIP: dissolved organic $\mathrm{N}$ and $\mathrm{P}$; ns: not significant.

\begin{tabular}{|lccccc|}
\hline X/Y & BDOC & BDON & BDOP & Prt (\%) & $\begin{array}{c}\text { Lip }+ \\
\text { Cho }(\%)\end{array}$ \\
\hline Salinity & $\mathrm{ns}$ & $\mathrm{ns}$ & $\mathrm{ns}$ & -0.4 & $0.7^{\mathrm{a}}$ \\
Temperature & 0.8 & 0.5 & 0.3 & $-0.8^{\mathrm{a}}$ & $0.7^{\mathrm{a}}$ \\
Chl a & $0.5^{\mathrm{a}}$ & $0.6^{\mathrm{a}}$ & $0.5^{\mathrm{a}}$ & $-0.7^{\mathrm{a}}$ & $0.5^{\mathrm{a}}$ \\
DIN & -0.5 & -0.3 & -0.3 & $0.5^{\mathrm{a}}$ & $-0.3^{\mathrm{a}}$ \\
DIP & -0.3 & -0.3 & -0.3 & $\mathrm{~ns}$ & $\mathrm{~ns}$ \\
a Data from 24 April & 2008 have been & omitted to reach \\
significant levels & \multicolumn{7}{l}{} \\
\hline
\end{tabular}

molar ratios of BDOM into the system of linear equations (Eqs. 8 to 10) as described by Álvarez-Salgado et al. (2006).

The average biochemical composition of marine phytoplankton consists of $46 \%$ Prt, $41 \%$ Cho + Lip and $12 \%$ Pho (Table 1). Accordingly, the average $( \pm \mathrm{SD})$ composition of BDOM degraded in the Ría de Vigo is $55 \pm 13 \%$ Prt, $32 \pm 15 \%$ Cho + Lip and $13 \pm 4 \%$ Pho (Table 4). It should be noted that the contribution of carbohydrates was inversely related with DIN and DIP and positively related with chl a (Table 3), showing that when nutrients become exhausted phytoplankton respond by producing carbohydrates, as previously observed (Fajon et al. 1999). Protein compounds showed the opposite pattern (Table 3), with decreasing percent contribution to the BDOM pool under N-deficient conditions.

\section{DOM stoichiometry}

The stoichiometry of DOM and BDOM was determined from the slopes of the DOM element-element plots (Fig. 4). These slopes are less than those of the bulk DOM, indicating that these $\mathrm{C}: \mathrm{N}: \mathrm{P}$ ratios only included the recently produced biomolecules containing $\mathrm{N}$ and $\mathrm{P}$. The slope of the relations between DOC, DON and DOP suggested an average $( \pm \mathrm{SE})$ ratio of $133( \pm 44): 14( \pm 3): 1$ for DOM. The significant origin intercepts in these linear regressions (Fig. 4) showed that a background level of DOC of $23 \pm 10$ and $54 \pm$ $13 \mu \mathrm{M}$ would persist when DON and DOP reached zero, respectively. Additionally, the origin intercept of the relationship between DON and DOP showed that 3 $\pm 1 \mu \mathrm{M}$ of DON would remain when DOP is depleted (Fig. 4), suggesting that degradation follows the sequence DOP > DON > DOC, which links DOM N 
Table 4 . Rate constants $( \pm \mathrm{SE})$ obtained by fitting the exponential decay model to the decrease in dissolved organic $\mathrm{C}\left(k_{\mathrm{DOC}}\right)$, $\mathrm{N}\left(k_{\mathrm{DON}}\right)$ and $\mathrm{P}\left(k_{\mathrm{DOP}}\right)$ over time. Also shown is the average $( \pm \mathrm{SE})$ percent contribution of phosphorus compounds (Pho), proteins

(Prt) and lipids and carbohydrates (Lip + Cho) to the degradable dissolved organic matter (DOM) during the sampling period in the Ría de Vigo. $\mathrm{R}^{2}$ : coefficient of determination; nd: not determined due to low recovery of DOP

\begin{tabular}{|c|c|c|c|c|c|c|c|c|c|}
\hline Date & $k_{\mathrm{DOC}}\left(\mathrm{d}^{-1}\right)$ & $\mathrm{R}^{2}$ & $k_{\mathrm{DON}}\left(\mathrm{d}^{-1}\right)$ & $\mathrm{R}^{2}$ & $k_{\mathrm{DOP}}\left(\mathrm{d}^{-1}\right)$ & $\mathrm{R}^{2}$ & Pho (\%) & $\begin{array}{l}\text { Prt } \\
(\%)\end{array}$ & $\begin{array}{c}\text { Lip }+ \\
\text { Cho }(\%)\end{array}$ \\
\hline $20 / 09 / 07$ & $0.35 \pm 0.04$ & 0.99 & $0.41 \pm 0.01$ & 0.96 & $0.60 \pm 0.10$ & 0.95 & $12 \pm 2$ & $42 \pm 6$ & $46 \pm 8$ \\
\hline $27 / 09 / 07$ & $0.23 \pm 0.05$ & 0.99 & $0.27 \pm 0.01$ & 0.98 & $0.34 \pm 0.04$ & 0.95 & $10 \pm 1$ & $50 \pm 6$ & $40 \pm 8$ \\
\hline 04/10/07 & $0.18 \pm 0.03$ & 0.98 & $0.28 \pm 0.01$ & 0.90 & $0.33 \pm 0.03$ & 0.91 & $13 \pm 1$ & $56 \pm 5$ & $31 \pm 6$ \\
\hline $31 / 01 / 08$ & $0.11 \pm 0.01$ & 0.97 & $0.20 \pm 0.01$ & 0.97 & $0.34 \pm 0.02$ & 0.92 & $16 \pm 1$ & $61 \pm 3$ & $23 \pm 5$ \\
\hline 07/02/08 & $0.11 \pm 0.02$ & 1.00 & $0.20 \pm 0.01$ & 0.92 & $0.29 \pm 0.03$ & 0.81 & $23 \pm 1$ & $67 \pm 1$ & $10 \pm 1$ \\
\hline $14 / 02 / 08$ & $0.20 \pm 0.01$ & 0.95 & $0.22 \pm 0.02$ & 0.94 & $0.27 \pm 0.04$ & 0.85 & $7 \pm 1$ & $61 \pm 6$ & $32 \pm 6$ \\
\hline $17 / 04 / 08$ & $0.20 \pm 0.02$ & 0.99 & $0.28 \pm 0.09$ & 0.93 & $0.37 \pm 0.04$ & 0.86 & $15 \pm 1$ & $54 \pm 5$ & $31 \pm 6$ \\
\hline $24 / 04 / 08$ & $0.20 \pm 0.02$ & 0.99 & $0.26 \pm 0.04$ & 0.93 & $0.32 \pm 0.05$ & 0.90 & $12 \pm 1$ & $79 \pm 1$ & $9 \pm 1$ \\
\hline $26 / 06 / 08$ & $0.30 \pm 0.08$ & 0.94 & $0.37 \pm 0.02$ & 0.91 & nd & nd & nd & nd & nd \\
\hline 03/07/08 & $0.19 \pm 0.05$ & 0.93 & $0.35 \pm 0.01$ & 0.91 & $0.40 \pm 0.04$ & 0.92 & $11 \pm 1$ & $49 \pm 6$ & $40 \pm 8$ \\
\hline $10 / 07 / 08$ & $0.30 \pm 0.05$ & 0.98 & $0.39 \pm 0.03$ & 0.94 & $0.45 \pm 0.20$ & 0.86 & $12 \pm 2$ & $34 \pm 6$ & $54 \pm 8$ \\
\hline
\end{tabular}
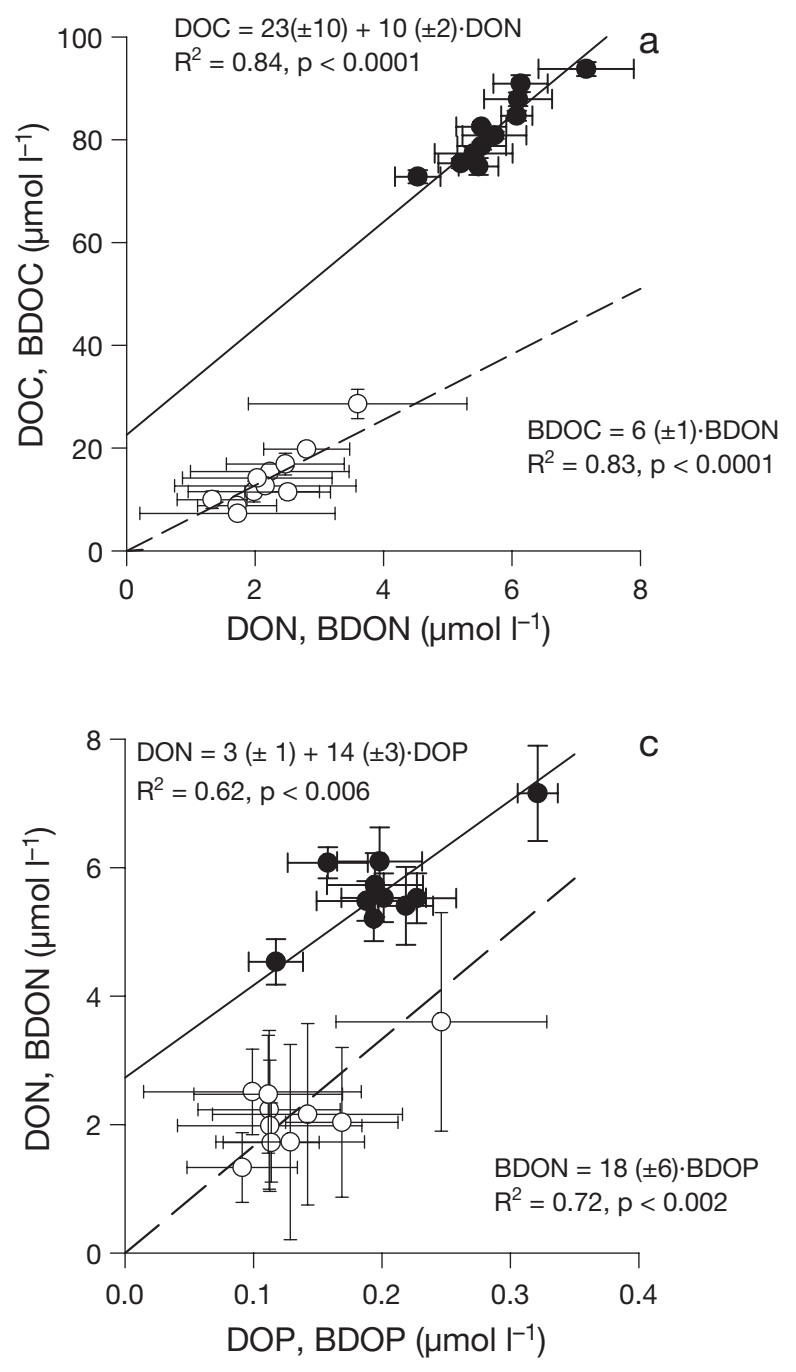

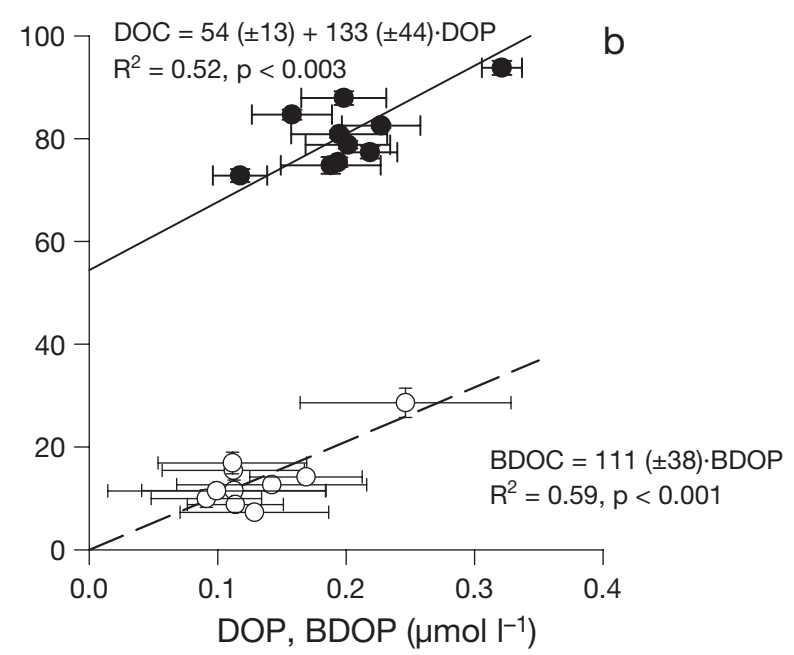

Fig. 4. Plots of (a) DON versus DOC (๑) and bioavailable DON (BDON) versus BDOC (O), (b) DOP versus DOC (•) and $\mathrm{BDOP}$ versus BDOC (O) and (c) DOP versus DON (๑) and BDOP versus BDON (O). Solid and dashed lines represent the corresponding regression; error bars are $\mathrm{SE}_{i} \mathrm{R}^{2}$ : coefficient of determination; $\mathrm{p}$ : significance level 
and P depletion with age, as found previously (Jackson \& Williams 1985, Hopkinson et al. 1997, 2002).

The C:N:P stoichiometry of BDOM, obtained from the slope of the significant $(p<0.05)$ linear relationships between BDOC, BDON and BDOP (Fig. 4), was $111( \pm 38): 18( \pm 6): 1$, not significantly different from the Redfield ratio (106:16:1, Redfield et al. 1963) and ratios found for recently produced organic matter (Garber 1984, Hopkinson et al. 1997). This stoichiometry is comparable to ratios previously reported for phytogenic DOM (Doval et al. 1997, Hansell \& Waterhouse 1997, Álvarez-Salgado et al. 2006).

\section{DOM rate constants}

Although the kinetics of DOM degradation can be modelled considering 2 (labile and refractory) or 3 (labile, semilabile and refractory) pools (e.g. Hopkinson et al. 1997, 2002), DOM should be considered as a continuum of pools with decreasing lability (Williams 2000). In our particular case, given the limited number of points of the degradation curves, the model used only considers labile and refractory DOM pools.

Average BDOM rate constants (Table 4 ) were $0.22 \pm$ $0.08 \mathrm{~d}^{-1}$ (average $\pm \mathrm{SE}$ ) for DOC $\left(k_{\mathrm{DOC}}\right), 0.29 \pm 0.08 \mathrm{~d}^{-1}$ for DON $\left(k_{\mathrm{DON}}\right)$ and $0.37 \pm 0.11 \mathrm{~d}^{-1}$ for DOP $\left(k_{\mathrm{DOP}}\right)$. The resulting half-lives of BDOM are as low as $3.3 \pm 0.9 \mathrm{~d}$ for DOC, $2.5 \pm 0.6 \mathrm{~d}$ for DON and $1.9 \pm 0.3 \mathrm{~d}$ for DOP, which are characteristic of very labile DOM (Hopkinson et al. 2002). Maximum rate constants were observed in autumn and summer and minimum rates in winter (Table 4 ) and they were positively correlated with BDOM (Table 2), demonstrating that higher BDOM concentrations would lead to faster mineralization rates, as observed in other coastal systems (Hopkinson et al. 1997, Lønborg et al. 2009).

Positive correlation was observed between $k_{\mathrm{DOC}}$ $k_{\mathrm{DON}}$ and $k_{\mathrm{DOP}}$ and the corresponding linear regression slopes, indicating that DOC and DON were degraded at a rate equivalent to $58 \pm 21$ and $77 \pm 15 \%$ (slope \pm SE) of DOP, respectively (Fig. 5). This is in agreement with the previous discussion of $\mathrm{C}: \mathrm{N}: \mathrm{P}$ stoichiometry, with the degradation rate of the DOM pools following the sequence DOP > DON > DOC (Garber 1984, Hopkinson et al. 1997, 2002).

The amount of BDOM degraded within the Ría de Vigo, calculated from the rate constants and the average flushing time of each sampling date, was $70 \pm 13 \%$ of BDOC (average $\pm \mathrm{SE}$ ), $81 \pm 8 \%$ of BDON and $88 \pm$ $5 \%$ of BDOP. Comparing these values with the in situ DIN and DIP levels suggests that 35 and $36 \%$ of bioavailable dissolved $\mathrm{N}$ and $\mathrm{P}$ were bound in DON and DOP, respectively. These calculations demonstrated that $\mathrm{N}$ and $\mathrm{P}$ budgets for this upwelling area
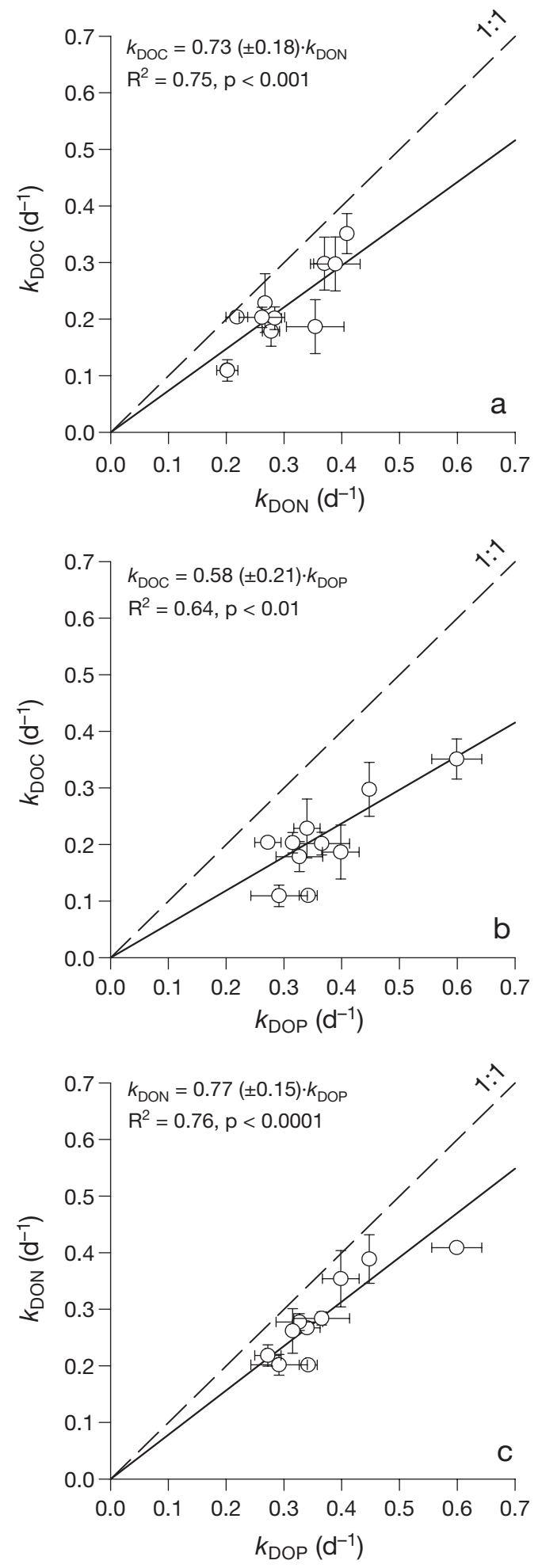

Fig. 5. X-Y plots of the relationship between bioavailable dissolved organic material (BDOM) rate constants $\left(\mathrm{d}^{-1}\right)$ predicted from the exponential decay model. (a) $k_{\mathrm{DON}}$ versus $k_{\mathrm{DOC}}$ (b) $k_{\mathrm{DOP}}$ versus $k_{\mathrm{DOC}}$ and (c) $k_{\mathrm{DOP}}$ versus $k_{\mathrm{DON}}$. The dashed line represents a 1:1 line where the rate constants are equal and the solid lines represent the regression lines found. Error bars are SE 
based only on DIN and DIP measurements would considerably underestimate the amounts of available $\mathrm{N}$ and $\mathrm{P}$. The amounts degraded depended both on the lability of BDOM and the variable flushing times, suggesting temporal differences in the export of BDOM from this coastal upwelling system. The exported BDOM was more C-rich than the DOM degraded within the ría, with an average ratio of 282 ( \pm 122$)$ :28 $( \pm 9): 1$ compared to $111( \pm 38): 18( \pm 6): 1$. The fate of the offshore exported C-rich BDOM, accumulation versus degradation, would depend on the demand of inorganic $\mathrm{N}$ and $\mathrm{P}$ by the heterotrophic bacteria in the adjacent oligotrophic waters to process that BDOM. In this sense, Álvarez-Salgado et al. (2007) have shown that less than $15 \%$ of the BDOM exported from the coastal upwelling region of the western Iberian Peninsula to NW Africa is consumed in the coastal transition zone.

Acknowledgements. This study was funded by a fellowship to C.L. from the early stage training site ECOSUMMER (MESTCT-2004-020501). We thank the captain, crew and technicians of the RV 'Mytilus' and the members of the Department of Oceanography of the Instituto de Investigacións Marinas for the collaboration during the sampling program. Access to vessel time was provided by the RAFTING project (Impact of the mussel raft culture on the benthic-pelagic coupling in a Galician Ria, grant no. CTM2007-61983/MAR). The valuable suggestions and comments by 4 anonymous reviewers are greatly appreciated.

\section{LITERATURE CITED}

Álvarez-Salgado XA, Gago J, Miguez BM, Pérez FF (2001) Net ecosystem production of dissolved organic carbon in a coastal upwelling system: the Ría de Vigo, Iberian margin of the North Atlantic. Limnol Oceanogr 46:135-147

Álvarez-Salgado XA, Figueiras FG, Pérez FF, Groom S and others (2003) The Portugal coastal counter current off NW Spain: new insights on its biogeochemical variability. Prog Oceanogr 56:281-321

Álvarez-Salgado XA, Nieto-Cid M, Gago J, Brea S, Castro CG, Doval MD, Pérez FF (2006) Stoichiometry of the degradation of dissolved and particulate biogenic organic matter in the NW Iberian upwelling. J Geophys Res 111, C07017, doi:10.1029/2004JC002473

Álvarez-Salgado XA, Arístegui J, Barton ED, Hansell DA (2007) Contribution of upwelling filaments to offshore carbon export in the subtropical Northeast Atlantic Ocean. Limnol Oceanogr 52:1287-1292

Álvarez-Salgado XA, Labarta U, Fernández-Reiriz MJ, Figueiras FG and others (2008) Renewal time and the impact of harmful algal blooms on the extensive mussel raft culture of the Iberian coastal upwelling system (SW Europe). Harmful Algae 7:849-855

Amon RMW, Benner R (1996) Bacterial utilization of different size classes of dissolved organic matter. Limnol Oceanogr 41:41-51

- Azam F (1998) Microbial control of oceanic carbon flux: the plot thickens. Science 280:694-696

Benner R, Opsahl S (2001) Molecular indicators of the sources and transformations of dissolved organic matter in the Mississippi river plume. Org Geochem 32:597-611

Benner R (2002) Chemical composition and reacivity. In: Hansell DA, Carlso CA (eds) Biogeochemistry of marine dissolved organic matter. Academic Press, San Diego, CA, p 59-90

Bronk DA (2002) Dynamics of dissolved organic nitrogen. In: Hansell DA, Carlson CA (eds) Biogeochemistry of marine dissolved organic matter. Academic Press, San Diego, CA, p 153-247

Carlson CA (2002) Chemical composition and reactivity. In: Hansell DA, Carlson CA (eds) Biogeochemistry of marine dissolved organic matter. Academic Press, San Diego, CA, p 91-151

Carlson CA, Ducklow HW (1995) Dissolved organic carbon in the upper ocean of the central equatorial Pacific Ocean, 1992: daily and finescale vertical variations. Deep-Sea Res II 42:639-656

Chavez FP, Toggweiler JR (1995) Physical estimates of global new production: the upwelling contribution. In: Summerhayes CP, Emeis KC, Angel MV, Smith RL, Zeitzschel B (eds) Upwelling in the ocean. Modern processes and ancient records. Wiley, New York, p 13-32

> Doval MD, Álvarez-Salgado XA, Pérez FF (1997) Dissolved organic matter in a temperate embayment affected by coastal upwelling. Mar Ecol Prog Ser 157: 21-37

> Druffel ERM, Williams PM, Bauer JE, Ertel J (1992) Cycling of dissolved and particulate organic matter in the open ocean. J Geophys Res 97:15639-15659

> Fajon C, Cauwet G, Lebaron P, Terzic S and others (1999) The accumulation of polysaccharides in plankton cells, its excretion and bacterial response during controlled experiments. FEMS Microbiol Ecol 29:351-363

> Fraga F, Ríos AF, Pérez FF, Figueiras FG (1998) Theoretical limits of oxygen: carbon and oxygen:nitrogen ratios during photosynthesis and mineralization of organic matter in the sea. Sci Mar 62:161-168

> Gago J, Álvarez-Salgado XA, Nieto-Cid M, Brea S, Piedracoba S (2005) Continental inputs of C, N, P and Si species to the Ría de Vigo (NW Spain). Estuar Coast Shelf Sci 65:74-82

Garber JH (1984) Laboratory study of nitrogen and phosphorus remineralization during the decomposition of coastal plankton and seston. Estuar Coast Shelf Sci 18:685-702

> Hansell DA, Carlson CA (1998a) Net community production of dissolved organic carbon. Global Biogeochem Cycles 12:443-453

- Hansell DA, Carlson CA (1998b) Deep-ocean gradients in the concentration of dissolved organic carbon. Nature 395: 263-266

Hansell DA, Waterhouse TY (1997) Controls on the distribution of organic carbon and nitrogen in the eastern Pacific Ocean. Deep-Sea Res I 44:843-857

Hansen HP, Koroleff F (1999) Automated chemical analysis. In: Grasshoff K, Kermling K, Ehrhardt M (eds) Methods of seawater analysis. Wiley-VCH, Weinheim, p 159-226

$>$ Hopkinson CS, Fry B, Nolin AL (1997) Stoichiometry of dissolved organic matter dynamics on the continental shelf of the northeastern U.S.A. Cont Shelf Res 17:473-489

Hopkinson CS, Vallino JJ, Nolin AL (2002) Decomposition of dissolved organic matter from the continental margin. Deep-Sea Res II 49:4461-4478

Jackson GA, Williams PM (1985) Importance of dissolved organic nitrogen and phosphorus to biological nutrient cycling. Deep-Sea Res Part II 32:223-235

> Lønborg C, Søndergaard M (2009) Microbial availability and degradation of dissolved organic carbon and nitrogen in 
two coastal areas. Estuar Coast Shelf Sci 81:513-520

Lønborg C, Davidson K, Álvarez-Salgado XA, Miller AEJ (2009) Bioavailability and bacterial degradation rates of dissolved organic matter in a temperate coastal area during an annual cycle. Mar Chem 113:219-226

Miyata K, Hattori A (1986) A simple fractionation method for determination of phosphorus components in phytoplankton: application to natural populations of phytoplankton in summer surface waters of Tokyo Bay. J Oceanogr Soc Jpn 42:255-265

Moran MA, Hodson RE (1990) Bacterial production on humic and nonhumic components of dissolved organic carbon. Limnol Oceanogr 35:1744-1756

Nausch M, Nausch G (2006) Bioavailability of dissolved organic phosphorus in the Baltic Sea. Mar Ecol Prog Ser 321:9-17

Nogueira E, Pérez FF, Ríos AF (1997) Seasonal patterns and long-term trends in an estuarine upwelling ecosystem (Ría de Vigo, NW Spain). Estuar Coast Shelf Sci 44:285-300

Redfield AC, Ketchum BK, Richards FA (1963) The influence of organisms on the composition of sea-water. In: Hill MN (ed) The sea, Vol. 2. The composition of sea water: comparative and descriptive oceanography. Wiley-Inter-

Editorial responsibility: Craig Carlson,

Santa Barbara, California, USA science, New York, p 26-77

Sokal FF, Rohlf FJ (1995) Biometry. Freeman, New York

Søndergaard M, Middelboe M (1995) A cross-system analysis of labile dissolved organic carbon. Mar Ecol Prog Ser 118:283-294

Williams PM, Druffel ERM (1987) Radiocarbon in dissolved organic matter in the central North Pacific Ocean. Nature 330:246-248

Williams PJleB (1995) Evidence for the seasonal accumulation of carbon-rich dissolved organic material, its scale in comparison with changes in particulate material and the consequential effect on net $\mathrm{C} / \mathrm{N}$ assimilation ratios. Mar Chem 51:17-29

Williams PJleB (2000) Heterotrophic bacteria and the dynamics of dissolved organic material. In: Kirchman DL (ed) Microbial ecology of the oceans. John Wiley \& Sons, New York, p 153-200

Wooster WS, Bakun A, McClain DR (1976) The seasonal upwelling cycle along the eastern boundary of the North Atlantic. J Mar Res 34:131-141

Yentsch CS, Menzel DW (1963) A method for the determination of phytoplankton chlorophyll and phaeophytin by fluorescence. Deep-Sea Res Oceanogr Abstr 10:221-231

Submitted: April 3, 2009; Accepted: August 12, 2009

Proofs received from author(s): November 8, 2009 